\title{
EVALUATION SIGNIFICANCE OF DIFFERENCES BETWEEN THE GEOTECHNICAL PARAMETERS OF THE LITHOLOGICAL ROCKS ROOF LAYERS, ABOVE MINING EXCAVATION
}

\author{
Jan KUDEŁKO ${ }^{1 *}$ \\ Maciej BODLAK ${ }^{2}$ \\ ${ }^{1}$ Faculty of Geoengineering, Mining and Geology, Wroclaw University of Technology, ul. Na Grobli 15, \\ 50-421 Wrocław Poland \\ ${ }^{2}$ KGHM CUPRUM Ltd. Research and Development Centre, 2-8 Gen. Sikorskiego St., 53-659 Wrocław, \\ Poland
}

\begin{abstract}
The article presents the results of the analysis data of the roof rocks geotechnical parameters in the conditions of the deep copper ore of the KGHM Polish Cooper mines. Using single factor analysis of variance and comparing means in two samples, the significance of differences between individual lithological layers (dolomite, anhydrite and rocks on their contact (dolomite-anhydrite breccia)) was evaluated in the aspect of constructing numerical simulations of the behavior of roof rocks above mining excavations. Based on the results of previous studies described in the works (Galiński 2005; Galiński, Lis and Mróz 2003), it was proposed to use Fisher-Snedecor analysis and t-Student test in order to justify the decision to consider individual lithological layers in numerical modeling of the rock mass around mining excavations. The problem raised in the article concerns the selection of lithological layers consider in numerical models of rock mass. Assuming too general (average values) physico-mechanical parameters in the simulation will generate incorrect results. On the other hand, consider of more lithological layers with insignificantly different physico-mechanical parameters may prove unnecessary, because this will not affect the accuracy of the results obtained.
\end{abstract}

Keywords: mining excavation, rock mass stability, numerical modelling, statistical analysis

* Corresponding author: jan.kudelko@pwr.edu.pl (J. Kudełko)

doi: 10.37190/MSC202713 


\section{INTRODUCTION}

The copper ore deposits exploited in the Legnica-Głogów Copper Belt belongs to a geological unit called the Fore Sudetic monocline, which is located in the southwest part of Poland. The monocline is formed of sedimentary rocks and its base is also formed of Proterozoic crystal rocks. The formation of rock layers comprising balance resources of copper ore have been identified as Permian. Regardless of the vertical range of the layers, the roof of the deposit is formed of the lower Zechstein dolomitelimestone rocks, while the floor is formed of the Rotliegend sandstone. The balance thickness of the deposit varies from several tens of centimetres to above ten meters. The rock layers in the Fore Sudetic monocline are inclined at approximately $3-5^{\circ}$. The layer depth increases in the northeast direction (Butra, Kicki 2003; Butra et al. 2013; Kozłowski, Kudełko 2014).

As the depth of excavations performed in underground copper ore mines increases, the lithological system of rocks in the main roof changes. The emerging salt bed divides the roof anhydrites into upper and lower layers. As the thickness of the salt bed increases, lower anhydrite and carbonate rock (dolomite) layers are reduced. The emergence of the salt bed is accompanied by a sudden reduction of the thickness of carbonate rocks, from approximately $70 \mathrm{~m}$ to $30 \mathrm{~m}$. This is the so-called barrier slope zone which roughly overlaps with the zone of the Paulinow syncline. Towards northwest, the thickness of the salt belt continues to increase and the thickness of the carbonate rocks continues to decrease (the so-called fore barrier zone). The thickness of the carbonate roof succession is reduced to approximately $5 \mathrm{~m}$ in the deepest regions of the copper ore mines in Poland.

Direct contact of carbonate rocks and anhydrites is varied. Sometimes the lithological boundaries are sharp and clear, however, for the most part, the roof part of the carbonate series is represented by a transition zone with a diversified structure and mineral composition, in which mainly dolomite, anhydrite and subordinate gypsum occur in varying proportions. The sulphate content is $35-65 \%$ of the rock volume (Szpak et al. 2016).

The type of rocks in the immediate roof is of key importance for the stability of mining excavations, as it determines their structure as well as physical and mechanical parameters. It also influences rock mass parameters and hence - rock mass classification, the choice of roof support type and forecasts of rockfall risk (Butra, Kudełko 2011; 2013).

\section{FORMULATING THE PROBLEM AND THE GOAL}

The purpose of this research was creation of a method for estimating the significance of differences in physical and mechanical parameters of lithological layers in the proc- 
ess of building numerical simulations of rock mass behavior around mining excavations. The article examines the problem on the example of roof rocks in the underground copper ore mines KGHM Polska Miedź S.A.

The analysis was aimed at to define an additional layer (the transition zone) from the dolomite layer. It is an important problem in the construction of numerical models representing rock behaviour in direct vicinity of mining excavations in the case when the dolomite layer has reduced thickness.

This paper presents a statistical analysis of the geomechanical parameters of rocks forming the roof in mining excavations, with a distinction made between the dolomite, the transition zone (dolomite and anhydrite mixture) and the anhydrite. The transition zone was defined on the basis of the changes of geomechanical parameters and lithological descriptions. As an example, where the thickness of the transition zone was determined on the basis of the reduction of geomechnical parameters, the geotechnical hole from "Polkowice-Sieroszowice" mine was given (Fabich 2015). The graph of the variability of the compressive strength $R_{c}$ of rocks from this hole is shown in Fig. 1.

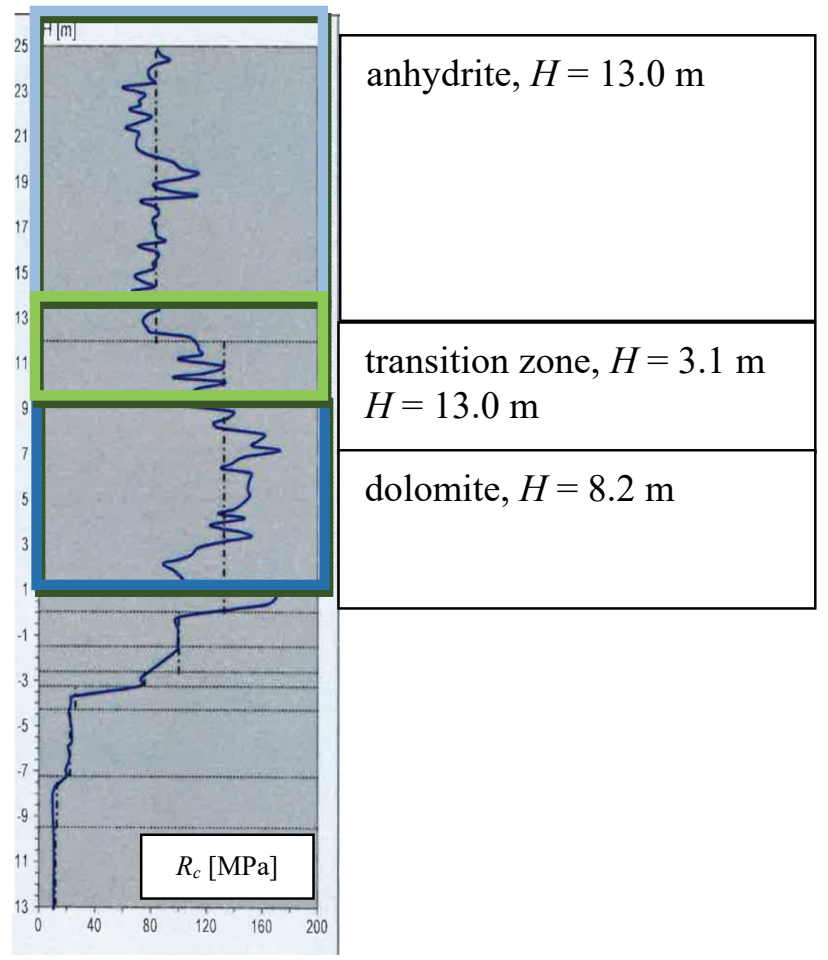

Fig. 1. Distribution of strength variability for uniaxial compression of roof rocks, with an indication of the transition zone based on the reduction of strength parameters (Fabich 2015) 
In another part of the holes, the transition zone between dolomite and anhydrite was separated by geologists in the lithological description. Analysis of 32 geotechnical holes shows that for the most part the contact zone is made of calcareous dolomites with numerous anhydrite outgrowths in the form of irregular mesh sizes from 0.1 to $3.0 \mathrm{~cm}$, has streaks, clay layers and divisibility of plates. The lithological descriptions are varied, so it is difficult to get a precise description and range of contact rocks. As an example the geotechnical hole from "Rudna" mine was given (Fabich 2014). The compressive strength $R_{c}$ and strain energy storage index $W_{e t}$ variability plot of rocks from this geotechnical hole is presented in Fig. 2.

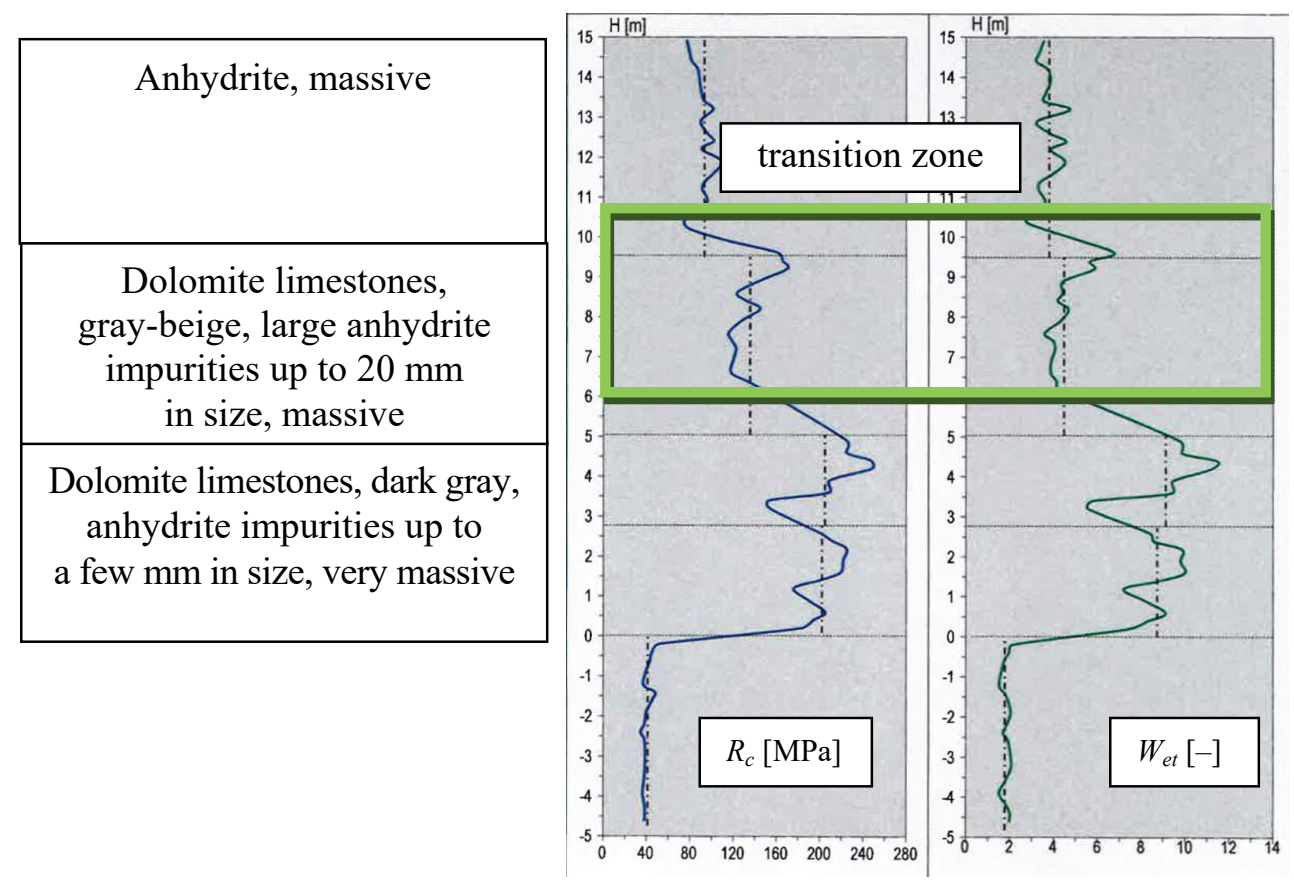

Fig. 2. Distribution of strength variability for uniaxial compression of roof rocks, with an indication of the transition zone based on the lithological description (Fabich 2014)

The range of the transition rocks is typically between $0.8 \mathrm{~m}$ and $5.5 \mathrm{~m}$ below the anhydrite layer. The analyses covered the following physical and mechanical properties of rocks:

- compressive strength $R_{c}, \mathrm{MPa}$;

- tensile strength $R_{r}, \mathrm{MPa}$;

- strain energy storage index $W_{e}$;

- Poisson's coefficient of lateral expansion $v$;

- Young's modulus of elasticity $E, \mathrm{GPa}$;

- volume density $\gamma, \mathrm{kg} / \mathrm{dm}^{3}$. 
Input data included in the statistical calculations were obtained from the documentation of geomechanical testing of rock properties occurring in geotechnical holes in the northern regions of the "Rudna" and "Polkowice-Sieroszowice" mines. To prepare the appropriate database, results from 32 holes drilled in roof excavations were used. The rock samples was tested in the laboratories of Rock Mechanics KGHM Cuprum, Research and Development Center.

It is stated that with the decrease in the thickness of carbonate rocks, their structure changes. Carbonate rocks that build the thin roof layer are transition links between dolomites and dolomitic limestones with numerous anhydrite impurities in various forms (laminas, interbeddings). These impurities point to the different structure of rocks which may translate into the variability of their physical and mechanical parameters. Presence of the transition zone rocks in the vicinity of the immediate roof of mining excavations may influence their stability.

\section{STATISTICAL ANALYSIS}

In order to verify the transition zone thesis, a numerical model was constructed with the use of statistical methods.

The problem in question is whether mean values of the parameters of dolomite, anhydrite and transition zone rocks differ greatly at an assumed significance level $\alpha$ of 0.05 (Galiński 2005; Galiński, Lis, Mróz 2003).

As the differences had to be determined between three lithological units, variance analysis was employed. In this case, the $F$ test (Fisher-Snedecor test) was used. A statistical analysis was also performed of the differences between mean parameter values of the dolomite and the transition zone. In this case, the $t$-Student test was sufficient (Galiński 2005; Galiński, Lis, Mróz 2003).

Testing the hypothesis consisted in calculating the value of the statistic $F$ and comparing it with the critical value obtained from the tables. Value $F_{k r}$ is read from the tables based on known degrees of freedom in the numerator and denominator of the statistic $F$, and on the defined significance level $\alpha$. Rejection of the zero hypothesis $\mathrm{H}_{0}$ means that the factor (in this case the division of the rock mass into dolomite and transition zone) is significant. In the case of the $t$-Student distribution, critical values for the assumed significance level are read from the tables and compared with the calculated values. If $t_{o b l}$ is greater than $t_{k r}$, the zero hypothesis $\mathrm{H}_{0}$ is rejected, with an implication that mean values are significantly different. In practice, distinguishing the contact zone from the dolomite layer in the construction of the numerical model may be viewed as sensible.

This chapter also presents the statistical methods used. Their description was based on the works (Galiński 2005; Galiński, Lis, Mróz 2003; Greń 1975). 
Formally, the assessed zero hypothesis $H_{o}$ sounds:

$$
\mathrm{H}_{0}: \mu_{1}=\mu_{2}=\ldots=\mu_{k},
$$

where $\mu_{1}$, for $i=1,2, \ldots, k$ mean the average values of the variable for the $i$-th level of the adopted factor. The alternative hypothesis (sometimes called the opposite) is formulated as follows $\mathrm{H}_{1}$ : at least two of the mediums $\mu_{1}, \mu_{2}, \mu_{1} \ldots, \mu_{k}$ are different.

If there are more partition factors, then multivariate analysis of variance or, in other words, multidirectional analysis is used. Computational relationships used are more complex and extensive. Then there is the problem of interactions, or interrelationships between factors, which significantly hinders the statistical assessment of final results (Galiński 2005).

\section{Single-factor analysis of variance}

The single factor analysis of variance, also known as the single classification, consists in assessing the quotient of the variance obtained from dividing the entire sample into groups. Inter-group variances and total sample variances before division are then calculated.

If through:

$$
\mu_{k}=\frac{1}{n_{k}} \sum_{j=1}^{n_{k}} x_{k j}
$$

we mark the group average, in other words - horizontally, and by

$$
\sum_{i=1}^{k} \sum_{j=1}^{n_{k}}\left(x_{i j}-\hat{\mu}\right)^{2}
$$

the average for the whole group, you can create sums of squares.

For the group we have then

$$
\sum_{i=1}^{k}\left(\mu_{k}-\hat{\mu}\right)^{2}
$$

and for the whole sample (set)

$$
\sum_{i=1}^{k} \sum_{j=1}^{n_{k}}\left(x_{i j}-\hat{\mu}\right)^{2}
$$

with appropriate degrees of freedom $(k-1)$ and $(n-k)$.

By calculating the appropriate variances, the so-called inter-group

$$
s_{1}^{2} \sum_{i=1}^{k} \frac{\left(\mu_{k}-\hat{\mu}\right)^{2} \cdot n_{i}}{(n-k)}
$$


and for the whole group

$$
s_{2}^{2} \sum_{i=1}^{k} \sum_{j=1}^{n_{k}} \frac{\left(x_{i j}-\hat{\mu}\right)^{2}}{(n-k)}
$$

the Fisher-Snedecor $F$ statistic is used in the form

$$
F_{o b l}=\frac{s_{1}^{2}}{s_{2}^{2}}
$$

on requirement $\bar{s}_{1}^{2}>\bar{s}_{2}^{2}$.

Checking the hypothesis $\mathrm{H}_{0}$ consists in calculating the value of the statistics $F$ compared to the critical value read from the tables. Tables read the value of $F_{k r}$, based on the known degrees of freedom of the numerator and denominator of $F$ statistics, and a set level of significance $\alpha$. If $F_{o b l}>F_{k r}$, then we say that a given factor has a significant impact on our measurements. Otherwise, its mean $F_{o b l}>F_{k r}$, it can be said that there are no grounds to reject the $\mathrm{H}_{0}$ hypothesis at the assumed significance level $\alpha$. Rejection of the hypothesis $\mathrm{H}_{0}$ means that the factor, which in this case is the division of the roof rock into anhydrite, translation zone and dolomite, is significant. In practice, it can be concluded that it is right to distinguish the anhydrite, contact zone and dolomite as different parts of the rock mass, in terms of $n$ numerical analysis of rock mass.

\section{Comparison of means in two samples}

The analysis for two samples is widely known. In this case, the t-Student statistics are used

$$
t=\frac{\hat{\mu}_{1}-\hat{\mu}_{2}}{\sqrt{\frac{n_{1} \cdot s_{1}^{2}+n_{2} \cdot s_{2}^{2}}{n_{1}+n_{2}-2} \cdot\left(\frac{1}{n_{1}}+\frac{1}{n_{2}}\right)}},
$$

where:

$n_{1}, n_{2}$ - number of samples,

$s_{1}^{2}, s_{2}^{2}$ - variances calculated from samples,

$\hat{\mu}_{1}, \hat{\mu}_{2}$ - average values.

Critical values for the adopted level of significance are read from the t-Student distribution tables and compared with the calculated values. If $t_{o b l}$ is greater than $t_{k r}$, then the hypothesis $\mathrm{H}_{0}$ should be rejected, which means that the means are significantly different. 


\section{DISCUSSION OF THE RESULTS}

The presented single-factor analysis of variance in which the equality of three mean parameters of rocks in the roof was assumed as a zero hypothesis $\mathrm{H}_{0}$ led to an observation that such hypothesis should be rejected in favour of an opposite hypothesis $\mathrm{H}_{1}$ : the means for the three lithological units are different. The calculations proved significant differences for all rock properties. On the other hand, in each calculation variant,

Table 1. Values of arithmetic means of roof rock parameters

\begin{tabular}{|l|c|c|c|c|c|c|}
\hline \multirow{2}{*}{ Rock type } & \multicolumn{7}{|c|}{ Rock parameters } \\
\cline { 2 - 7 } & $R_{c}$ & $R_{r}$ & $W_{e t}$ & $v$ & $E_{s}$ & $\gamma$ \\
\hline Anhydrite & 90.24 & 5.04 & 3.14 & 0.23 & 41.79 & 2.94 \\
\hline Transition zone & 125.81 & 6.98 & 4.62 & 0.23 & 47.66 & 2.72 \\
\hline Dolomite & 155.71 & 8.55 & 5.97 & 0.23 & 61.71 & 2.74 \\
\hline
\end{tabular}

Table 2. Value of the statistic $F$ and the statistic $t$

\begin{tabular}{|c|c|c|c|c|c|c|c|}
\hline \multirow{2}{*}{\multicolumn{2}{|c|}{ Statistic }} & \multicolumn{6}{|c|}{ Rock parameters } \\
\hline & & $R_{c}$ & $R_{r}$ & $W_{e t}$ & $v$ & $E_{s}$ & $\gamma$ \\
\hline \multirow{10}{*}{ 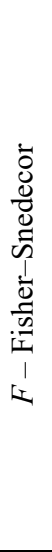 } & \multicolumn{7}{|c|}{ dolomite-transition zone-anhydrite } \\
\hline & $F_{o b l}$ & 550.61 & 252.08 & 381.62 & 1.54 & 174.04 & 1229.91 \\
\hline & $\begin{array}{l}\text { quantile ranks } \\
\text { of the } F \text { distribution }\end{array}$ & $<10^{-2} 1 \%$ & $<10^{-2} 1 \%$ & $<10^{-2} 1 \%$ & $21.6 \%$ & $<10^{-2} 1 \%$ & $<10^{-2} 1 \%$ \\
\hline & \multicolumn{7}{|c|}{ transition zone-anhydrite } \\
\hline & $F_{o b l}$ & 348.87 & 153.48 & 301.59 & 0.09 & 39.31 & 2039.69 \\
\hline & $\begin{array}{l}\text { quantile ranks } \\
\text { of the } F \text { distribution }\end{array}$ & $<10^{-2} 1 \%$ & $<10^{-2} 1 \%$ & $<10^{-2} 1 \%$ & $76.3 \%$ & $<10^{-2} 1 \%$ & $<10^{-2} 1 \%$ \\
\hline & \multicolumn{7}{|c|}{ dolomite-transition zone } \\
\hline & $F_{o b l}$ & 92.78 & 46.98 & 68.31 & 1.20 & 74.27 & 7.98 \\
\hline & $\begin{array}{l}\text { quantile ranks } \\
\text { of the } F \text { distribution }\end{array}$ & $<10^{-2} 1 \%$ & $<10^{-2} 1 \%$ & $<10^{-2} 1 \%$ & $27.4 \%$ & $<10^{-2} 1 \%$ & $0.48 \%$ \\
\hline & number of measurements $n$ & 1711 & 733 & 1673 & 599 & 1668 & 2461 \\
\hline \multirow{4}{*}{ 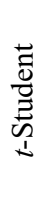 } & \multicolumn{7}{|c|}{ dolomite-transition zone } \\
\hline & $t_{o b l}$ & 9.78 & 7.05 & 8.77 & 1.18 & 9.11 & 4.43 \\
\hline & $\begin{array}{l}\text { quantile ranks } \\
\text { of the } t \text { distribution }\end{array}$ & $<10^{-2} 1 \%$ & $<10^{-2} 1 \%$ & $<10^{-2} 1 \%$ & $23.9 \%$ & $<10^{-2} 1 \%$ & $<10^{-2} 1 \%$ \\
\hline & number of measurements $n$ & 900 & 454 & 883 & 331 & 891 & 1393 \\
\hline
\end{tabular}

The table above indicates: compressive strength $R_{c}$, MPa; tensile strength $R_{r}, \mathrm{MPa}$; strain energy storage index $W_{e}$; Poisson's coefficient of lateral expansion $v$; Young's modulus of elasticity $E$, GPa; volume density $\gamma, \mathrm{kg} / \mathrm{dm}^{3}$. 
regardless of the method, in relation to the Poisson's coefficient, it is possible to conclude that the differences between individual rock layers in the roof are insignificant.

The calculation results are shown in Tables 1 and 2. In order to demonstrate the degree of variation, the $F$ (Fisher-Snedecor) value distribution was prepared (Figs. 3-5). The quantiles in the tables correspond to the calculated values of statistics $F$ and $t$. They were compared with the assumed value of $\alpha=0.05$ in accordance with the hypothesis testing rules.

By using the functions of MS Excel ${ }^{\circledR}$ "TINV(probability, deg freedom)" critical values were obtained, the exceeding of which means that the differences between parameters are insignificant

- critical value of the statistic for the Fisher-Snedecor test, $F_{k r}=3.00$,

- critical value for the $t$-Student statistic, $t_{k r}=2.00$.

The above statistical analysis shows that the physico-mechanical parameters of selected roof rock layers are significantly different. Confirmation of this thesis was obtained by two independent methods.

With regard to anhydrite and dolomite, the above conclusion may be obvious, but in the case of dolomite and the contact zone, it is more difficult to establish without calculations. Looking at figure 3 and table 2, it can be seen that the largest differences are between anhydrite and dolomite. On the other hand, the lowest values of $F_{o b l}$ statistics were obtained by examining the differences between the dolomite and the contact zone.

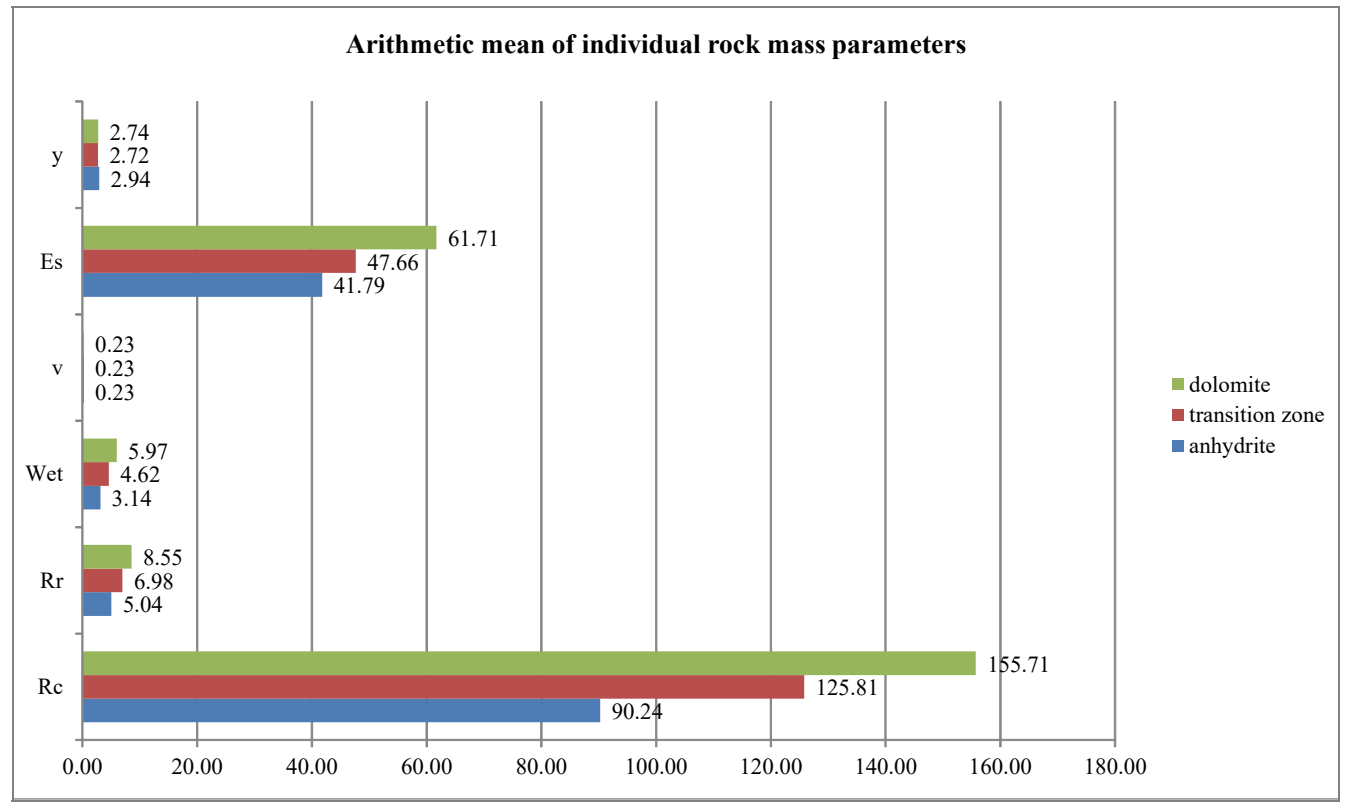

Fig. 3. Arithmetic means of individual rock mass parameters 


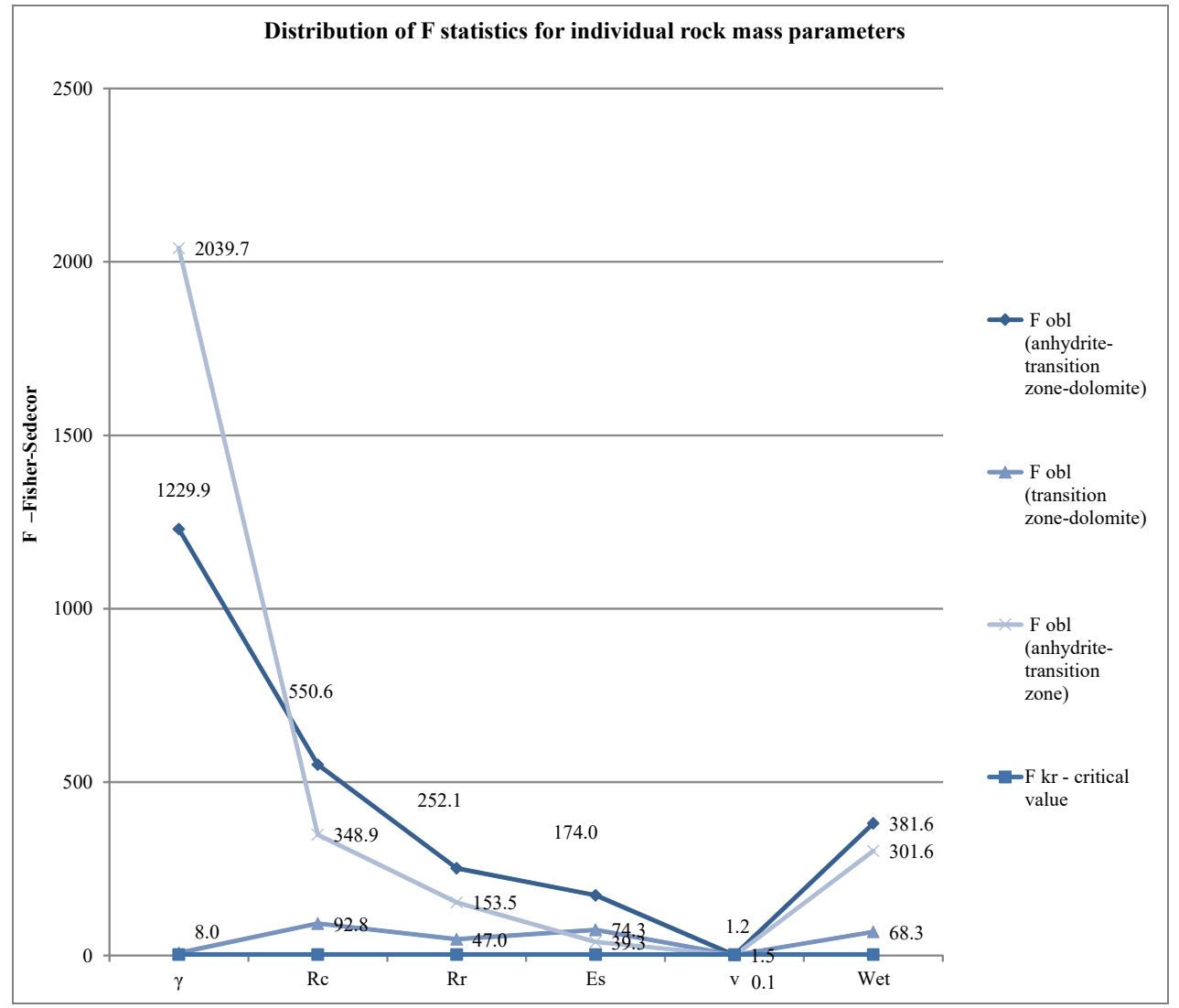

Fig. 4. Distribution of the F statistic for individual rock mass parameters

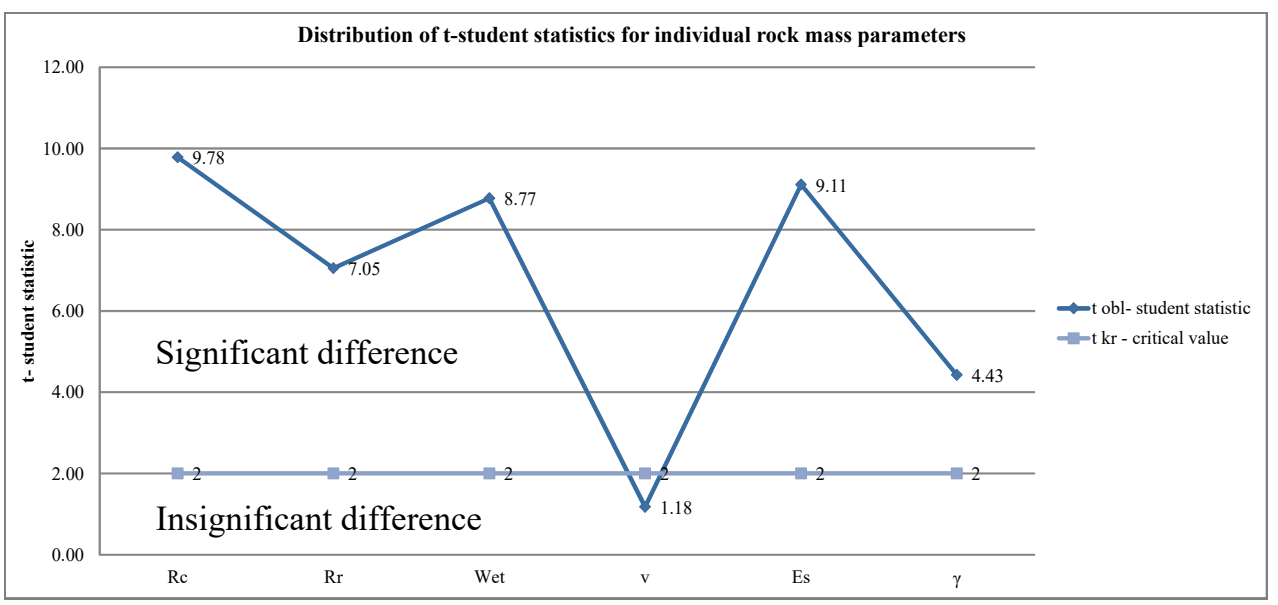

Fig. 5. Distribution of the t-Student statistic for individual rock mass parameters 


\section{NUMERICAL ANALYSIS}

With the use of mean strength and deformation parameters of rocks as well as the above-described statistical analysis, it was possible to prepare a numerical analysis of rock mass behaviour in the case when taking into account the additional lithological layer (transition zone - dolomite-anhydrite breccia). The strength and deformation parameters of rocks were characterized with the use of the RocLab 1.0 software and the Hoek-Brown classification (Hoek 1994), (Hoek, Brown 1997), (Hoek, Marinos 2000). The parameters adopted in the modeling were determined on the basis of mean values from laboratory tests on rock samples, presented in Table 1. The reduced physico-mechanical parameters of the roof rocks in the first variant model are shown in Table 3. Numerical calculations were performed in the Itasca Flac 3D v.6.0 software, which is based on Finite Difference Method, owned by the KGHM Cuprum Research and Development Center. The performed numerical simulations and the Mohr-Coulomb failure criterion served to determine distribution maximum principal stress in the roof of mining excavation.

The model was based on a stress state, which is characteristic for the depth of approximately $1100 \mathrm{~m}$ b.g.l., resulting from the theory of elasticity (Terzaghi, Richart 1952).

The numerical analysis was performed for a single excavation. The heading has a trapezoidal shape and the sidewall inclination angle is $10^{\circ}$. The height of the heading is $3.0 \mathrm{~m}$ and its width at the roof is $7.0 \mathrm{~m}$. The shape and dimensions of the excavation correspond to the geometry of excavations in the KGHM Polish Cooper conditions.

Table 3. Strain and stress parameters of roof rocks tested (I variant)

\begin{tabular}{|l|c|c|c|c|c|c|c|c|c|}
\hline Rock type & Structure & $\begin{array}{c}h \\
{[\mathrm{~m}]}\end{array}$ & $\begin{array}{c}\sigma_{t} \\
{[\mathrm{MPa}]}\end{array}$ & $\begin{array}{c}E_{r m} \\
{[\mathrm{MPa}]}\end{array}$ & $\begin{array}{c}v \\
{[-]}\end{array}$ & $\begin{array}{c}\varphi_{\text {peak }} \\
{\left[{ }^{\circ}\right]}\end{array}$ & $\begin{array}{c}\varphi_{\text {resid }} \\
{\left[{ }^{\circ}\right]}\end{array}$ & $\begin{array}{c}c_{\text {peak }} \\
{[\mathrm{MPa}]}\end{array}$ & $\begin{array}{c}c_{\text {resid }} \\
{[\mathrm{MPa}]}\end{array}$ \\
\hline Anhydrite & blocky & 95.0 & 1.954 & 48918.3 & 0.20 & 39.001 & 37.050 & 8.053 & 1.611 \\
\hline $\begin{array}{l}\text { Transition } \\
\text { zone } \\
\begin{array}{l}\text { Dolomite- } \\
\text {-anhydrite } \\
\text { breccia }\end{array}\end{array}$ & seamy & 1.0 & 0.779 & 5806.2 & 0.22 & 30.880 & 29.005 & 2.190 & 0.438 \\
\hline Dolomite & blocky & 4.0 & 1.727 & 25845.9 & 0.22 & 27.374 & 26.005 & 9.388 & 1.877 \\
\hline
\end{tabular}

The table above indicates: $h$ - thickness of the rock layers, $E_{r m}$ - Young's modulus, $v$ - Poisson's ratio, $\sigma_{t}-$ tensile strength, $\varphi_{\text {peak }}-$ angle of internal friction, $c_{\text {peak }}-$ cohesion, $\varphi_{\text {dyl }}-$ dilatancy angle, $\varphi_{\text {resid }}-$ residual angle of internal friction, $c_{\text {resid }}-$ residual cohesion.

The edges of the analysed plate were equipped with supports which do not slide either in the vertical or in the horizontal direction. The edges of the plate should be at a distance of approximately $100.0 \mathrm{~m}$ from the extreme points on each side of the ana- 
lysed excavation (the roof and the side walls). In the middle of the plate, in the zone where the excavation is driven, elements of smaller dimensions are used (element grid density region) in order to increase the accuracy of numerical calculations. The rock medium was described with an elastic-perfectly-plastic model (floor and face height) and with an elastic-perfectly-plastic model with softening (roof).

In order to investigate whether the extraction from the dolomite layer of the transition zone lithological layer in the model causes significant changes in the results of numerical modelling, two variants of calculations were performed. In the first variant, simulations were performed with three lithological layers in the roof (dolomite $4.0 \mathrm{~m}$ thick, transition zone $1.0 \mathrm{~m}$ thick and anhydrite $95.0 \mathrm{~m}$ thick).

In the second variant, the transition zone and dolomite lithological layers were connected into one carbonate layer $5.0 \mathrm{~m}$ thick and with average parameters (weighted average). The weight in the calculated mean was the layer thickness.

The reduced physico-mechanical parameters of the roof rocks in the second variant model are shown in Table 4.

Table 4. Strain and stress parameters of roof rocks tested (II variant)

\begin{tabular}{|l|c|c|c|c|c|c|c|c|c|}
\hline Rock type & Structure & $\begin{array}{c}h \\
{[\mathrm{~m}]}\end{array}$ & $\begin{array}{c}\sigma_{t} \\
{[\mathrm{MPa}]}\end{array}$ & $\begin{array}{c}E_{r m} \\
{[\mathrm{MPa}]}\end{array}$ & $\begin{array}{c}v \\
{[-]}\end{array}$ & $\begin{array}{c}\varphi_{\text {peak }} \\
{\left[{ }^{\circ}\right]}\end{array}$ & $\begin{array}{c}\varphi_{\text {resid }} \\
{\left[{ }^{\circ}\right]}\end{array}$ & $\begin{array}{c}c_{\text {peak }} \\
{[\mathrm{MPa}]}\end{array}$ & $\begin{array}{c}c_{\text {resid }} \\
{[\mathrm{MPa}]}\end{array}$ \\
\hline Anhydrite & blocky & 95.0 & 1.954 & 48918.3 & 0.20 & 39.001 & 37.050 & 8.053 & 1.611 \\
\hline Dolomite & blocky & 5.0 & 1.437 & 21837.9 & 0.22 & 28.075 & 26.670 & 7.949 & 1.589 \\
\hline
\end{tabular}

The table above indicates: $h$ - thickness of the rock layers, $E_{r m}$ - Young's modulus, $v$ - Poisson's ratio, $\sigma_{t}-$ tensile strength, $\varphi_{\text {peak }}-$ angle of internal friction, $c_{\text {peak }}-$ cohesion, $\varphi_{\text {dyl }}-$ dilatancy angle, $\varphi_{\text {resid }}-$ residual angle of internal friction, $c_{\text {resid }}-$ residual cohesion.

The here presented single-factor analysis of variance allows a conclusion that it seems sensible to distinguish a dolomite-anhydrite layer having reduced strength and deformation parameters and located within the limits of the dolomite layer. Further laboratory tests of rocks present in the boundary between the anhydrite layer and the dolomite layer is justified. The conducted statistical analysis and numerical analysis demonstrates that taking into account of individual lithological layers in models of the rock mass behaviour (in particular in the excavation roof) can significantly affect the results obtained. In view of the above, it is recommended to use the statistical methods described in the article in order to select lithological layers to considered in geomechanical analyses.

Figures 6 and 7 show the results of both numerical models in the form of maximum principal stress distribution. The pressure values shown in the figures are expressed in $\mathrm{MPa}$.

In order to better present the differences between the obtained results, Fig. 8 presents a graph of the variability of the maximum principal stress above the mining excavation. The stresses were measured along the axis of the excavation, $15.0 \mathrm{~m}$ deep into the roof. 


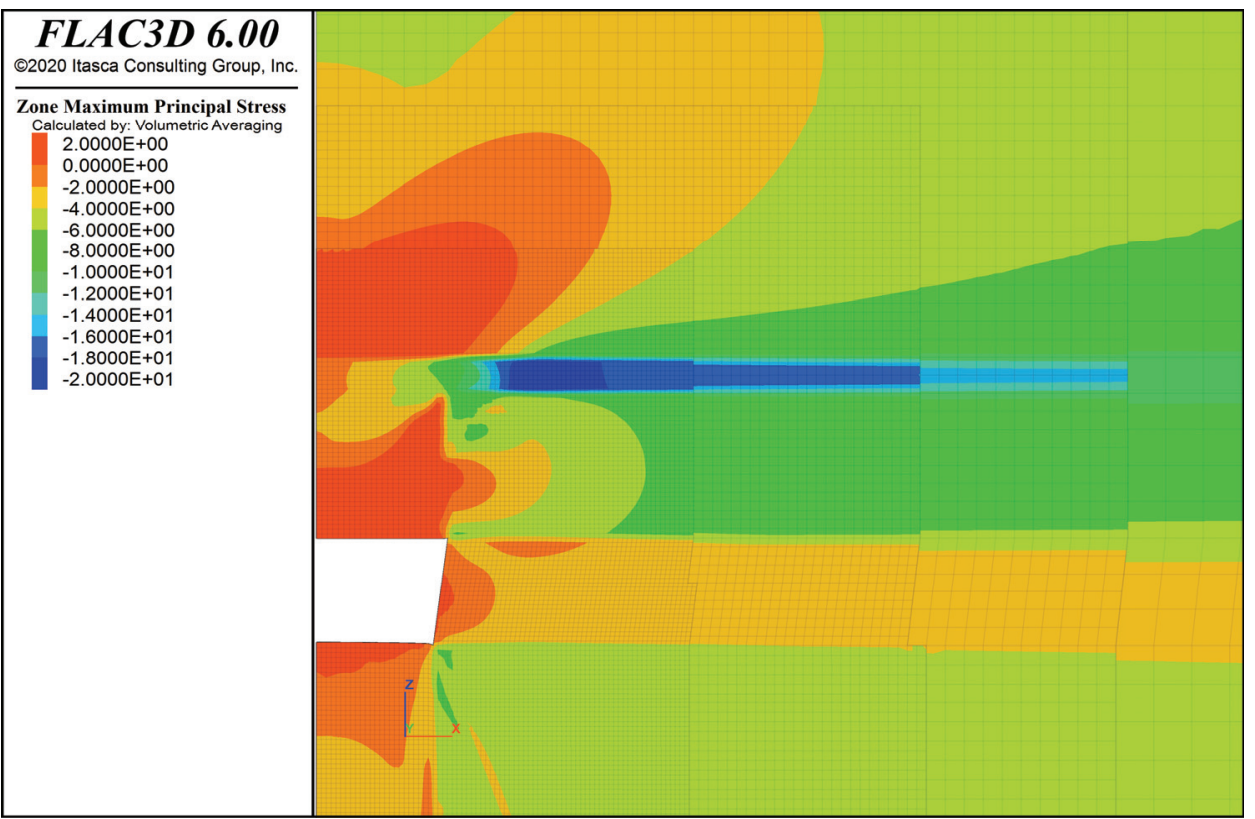

Fig. 6. Distribution of the maximum principal stress (Variant I)

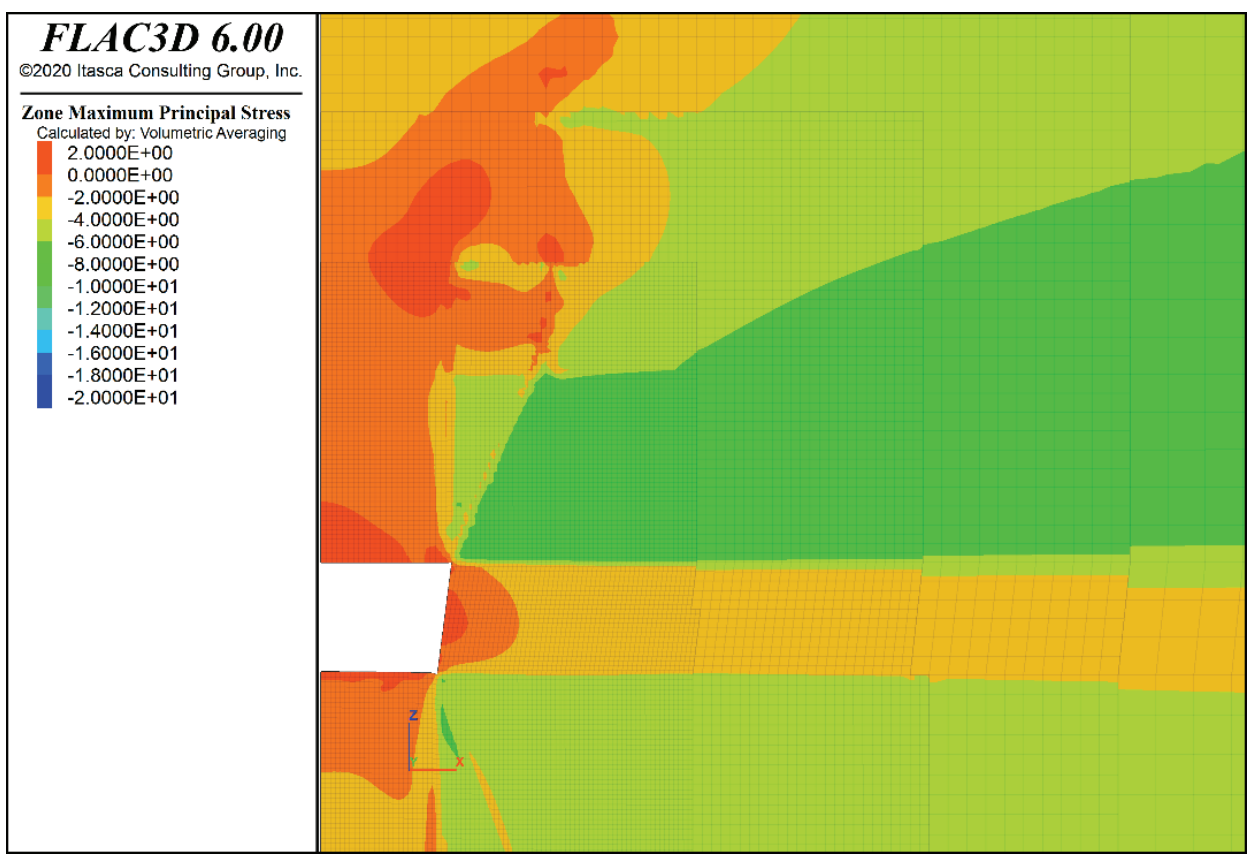

Fig. 7. Distribution of the maximum principal stress (Variant II) 


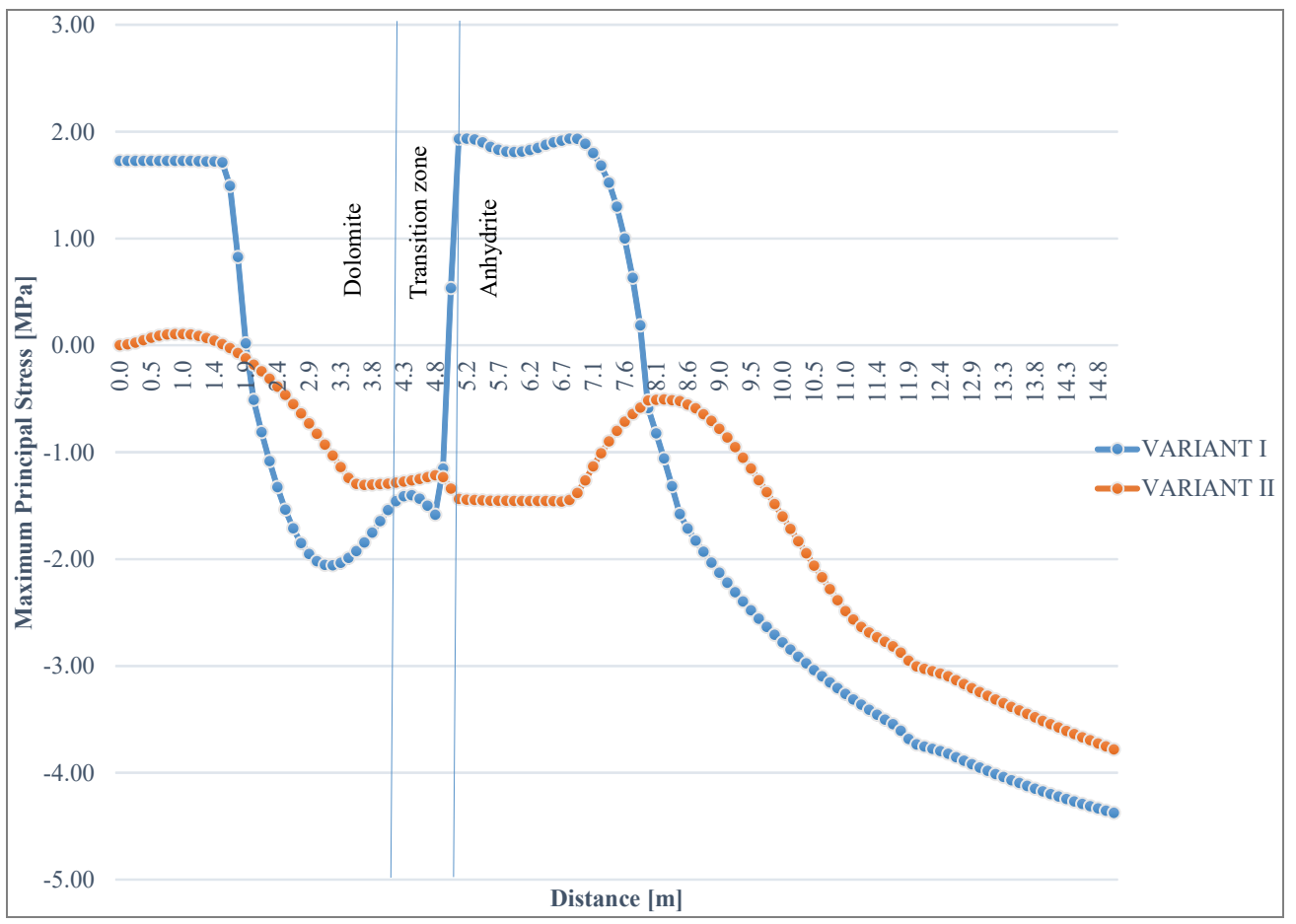

Fig. 8. Comparison of the stress distribution in the excavation roof for both variants

The graph (Fig. 8) shows large discrepancies between the results of both numerical models. The decision to connection or divide lithological layers strongly influences the obtained results.

\section{CONCLUSIONS}

The results presented in the article show that it is justified to use statistical analyses in assessing the significance of differences between the physico-mechanical parameters of lithological layers. For this purpose, it is recommended to use the comparison of means in two samples or the single-factor analysis of variance at the stage of building numerical models (Galiński 2005). In a case of when the cited statistical calculations proved significant differences for rock layers properties, the inclusion them in rock mass models should be considered. As a result, averaging the parameters of rock layers may translate into incorrect results. The numerical calculations presented in the article show that the obtained stress values are completely different depending on the adopted in the variants model structure. The above research will be continued in other geotechnical cases. In the future, the problem of modelling rock pillars, built of three 
lithological layers with different geotechnical properties, will be discussed. Using the same methodology, it will be determined whether the averaging of the parameters of individual layers has a significant impact on the results of numerical modelling of the behaviour of pillars in the room and pillar exploitation system.

\section{REFERENCES}

BUTRA J., KICKI J., 2003, Ewolucja technologii eksploatacji złóż rud miedzi w polskich kopalniach. Biblioteka Szkoły Eksploatacji Podziemnej nr 17, Kraków (in Polish).

BUTRA J., KUDEŁKO J., 2011, Rockburst hazard evaluation and prevention methods in Polish copper mines, Cuprum - Czasopismo Naukowo-Techniczne Górnictwa Rud, nr 4, s. 5-20.

BUTRA J., KUDEŁKO J., 2013, Rockburst Prevention Methods in Polish Copper Mines, World Mining Congress in Montreal, Canada.

BUTRA J., KUDEŁKO J., SZPAK M., 2013, Development of Mining Methods for Deep-Seated Copper Ore Deposits in Associated Hazard Conditions, World Mining Congress in Montreal, Canada.

GALIŃSKI A., 2005, Ocena zależności między parametrami skat stropowych i spagowych na przykładzie wybranego rejonu kopalni Rudna, Czasopismo Górnictwo-Geologia, Z. 3/1, R. 29 (in Polish).

GREŃ J., 1975, Statystyka matematyczna. Modele i zadania, PWN, Warszawa (in Polish).

GALIŃSKI A., LIS J., MRÓZ J., 2003, Ocena zależności pomiędzy geomechanicznymi parametrami skat złożowych i otaczajacych na przykładzie poludniowo-wschodniego rejonu kopalni "Lubin". XXV ZSMG, Wyd. Politechniki Wrocławskiej, Wrocław (in Polish).

HOEK E., 1994, Strength of rock and rock masses. ISRM News Journal, 2(2), 4-16.

HOEK E., BROWN E.T., 1997, Practical estimates of rock mass strength, Int. J. of Rock Mechanics and Min. Sc., Vol. 34, No. 8, 1165-1186.

HOEK E., MARINOS P., 2000, GSI: a geologically friendly tool for rock mass strength estimation. Proceedings of the GeoEng 2000 at the International Conference on Geotechnical and Geological Engineering, Melbourne, pp. 1422-1446.

KOZŁOWSKI T., KUDEŁKO J., 2014, Weryfikacja doboru obudowy kotwowej w warunkach zaburzeń tektonicznych w kopalni Lubin, Cuprum - Czasopismo Naukowo-Techniczne Górnictwa Rud, nr 4, s. 55-71 (in Polish).

FABICH S., 2014, 2015, Laboratory tests of geomechanical properties of rocks. Selected Hole, KGHM Cuprum Research and Development Center, Wrocław (unpublished) (in Polish).

SZPAK M., 2016, Wpływ budowy geologicznej skat stropowych w rejonach występowania zredukowanej miąższości skat węglanowych na stan zagrożenia zawałowego w polach eksploatacyjnych O/ZG Rudna i O/ZG Polkowice-Sieroszowice. KGHM Cuprum Research and Development Center, Wrocław (unpublished) (in Polish).

TERZAGHI K., RICHART F., 1952, Stresses in rock about cavities, Geotechnique, Vol. 3, June, pp. 57-90. 